\title{
Abundance and relationship of bacteria with transparent exopolymer particles during the 1996 summer monsoon in the Arabian Sea
}

\author{
N Ramaiah, V V S S Sarma, Mangesh Gauns, M Dileep Kumar and M Madhupratap \\ National Institute of Oceanography, Dona Paula, Goa, India.
}

\begin{abstract}
Bacterial abundance and production, numbers, sizes and concentrations of transparent exopolymer particles (TEP) and total organic carbon (TOC) were measured during the 1996 summer monsoon to understand the relationship between TEP, the most labile particulate organic carbon, and bacteria. While high regional variability in the vertical distribution of TOC was discernible, TEP concentrations were high in surface waters at $18-20^{\circ} \mathrm{N}$ along $64^{\circ} \mathrm{E}$ with concentrations well over $25 \mathrm{mg}$ alginic acid equivalents $1^{-1}$ due to upwelling induced productivity. Their concentrations decreased with depth and were lower between 200 and $500 \mathrm{~m}$. Bacterial concentrations were up to $1.99 \times 10^{8} \mathrm{l}^{-1}$ in the surface waters and decreased by an order of magnitude or more at depths below $500 \mathrm{~m}$. A better relationship has been found between bacterial abundance and concentrations of TEP than between bacteria and TOC, indicating that bacterial metabolism is fueled by availability of TEP in the Arabian Sea. Assuming a carbon assimilation of $33 \%$, bacterial carbon demand (BCD) is estimated to be 1.017 to $4.035 \mathrm{~g} \mathrm{C} \mathrm{m}^{-2}$ $\mathrm{d}^{-1}$ in the surface waters. The observed TEP concentrations appear to be sufficient in meeting the surface and subsurface BCD in the northern Arabian Sea.
\end{abstract}

\section{Introduction}

The predominant physical factors influencing the northern Arabian Sea biogeochemistry are strong, semi-annual reversals in monsoonal winds. Such reversing winds bring about very large seasonal changes in primary production (Qasim 1982; Banse 1994; Madhupratap et al 1996a), with consequences for the biological pump. The latest findings from the JGOFS disprove many previous long-held notions, and suggest high production during the northeast monsoon (Smith et al 1998; Burkill et al 1993; Prasanna Kumar et al 2000). Aggregation and sinking flux of organic matter following phytoplankton blooms are common in marine ecosystems (Takahashi 1986; Bodungen et al 1986), including the Arabian Sea where seasonal changes in sedimentation rates are high (Nair et al 1989; Haake et al 1993). The Arabian Sea also has an extensive denitrification zone at mid depths (Naqvi 1994; Naqvi et al 1998). Bacterioplankton often constitutes a bulk of carbon biomass in pelagic ecosystems
(Biddanda and Benner 1997; Wiebinga et al 1997), and utilizes a large fraction of the sinking particulate organic matter, converting it to a non-sinking carbon pool (Smith et al 1995). Thus, interaction between sinking organics (fecal pellets and /or post-bloom aggregates) and heterotrophic bacteria is important in supporting life below the euphotic zone.

Under the Joint Global Ocean Flux Study (JGOFS) programmes, there have been a number of recent studies on the abundance (and production) of bacteria in the Arabian Sea (Burkill et al 1993; Ducklow 1993; Wiebinga 1994; Ramaiah et al 1996; Goosen et al 1997; Veldhuis et al 1997; Wiebinga et al 1997; Campbell et al 1998). Seasonal variations are clearly seen with higher abundance and production rates during spring and fall inter-monsoons (Ramaiah et al 1996; Campbell et al 1998; Pomroy and Joint 1999). However, the relationship of bacteria with available organic carbon in situ is not well understood. The presence of free, large, discrete polymer particles, known as transparent exopolymer particles (TEP) which are easily

Keywords. Bacteria; TEP; primary production; organic carbon; zooplankton; Arabian Sea. 
assimilable by bacteria (Passow and Alldredge 1995, Smith et al 1995) have been demonstrated to be of great significance in the biogeochemistry of the marine regimes (Alldredge et al 1993; Kumar et al 1998). In the light of this recent discovery, we quantified TEP during the summer monsoon of 1996 for the first time from the Arabian Sea with an aim to understand its relationship with bacteria.

\section{Material and Methods}

This study was carried out during the cruise 115 of ORV Sagar Kanya during the summer (southwest) monsoon (August 4th-30th, 1996) as a part of the JGOFS India Programme. Stations were occupied along $64^{\circ} \mathrm{E}$ from $13^{\circ} \mathrm{N}$ to $21^{\circ} \mathrm{N}$ (figure 1). Water samples were collected from the upper $1000 \mathrm{~m}$ using CTD rosette and analysed for bacterial abundance and production and for estimating numbers, sizes and concentrations of TEP. Bacterial production was measured only in the top $150 \mathrm{~m}$.

Immediately after collection aliquots $(50 \mathrm{ml})$ of seawater were fixed with $0.22 \mu \mathrm{m}$ pre-filtered formaldehyde (to a final concentration of $3.7 \%$ ) for counting total bacterial cells. These samples were stored in the dark at $4^{\circ} \mathrm{C}$ as per the JGOFS Protocols (UNESCO 1994) until taken for counting within a week of returning from the cruise. Acridine orange direct counts (AODC) of bacteria were carried out following Parsons et al (1984) by using 100X oil immersion objective on an Olympus BH2 epifluoroscence microscope. Aliquots of two to six ml (with higher volumes from deeper samples) were stained with acridine orange (0.001\% final concentration) for 5 minutes, filtered $(0.22 \mu \mathrm{m}$ black Nuclepore filters $)$ and prepared for microscopy. Bacterial cells in ca. 25 microscopic fields were counted and the mean cell numbers per

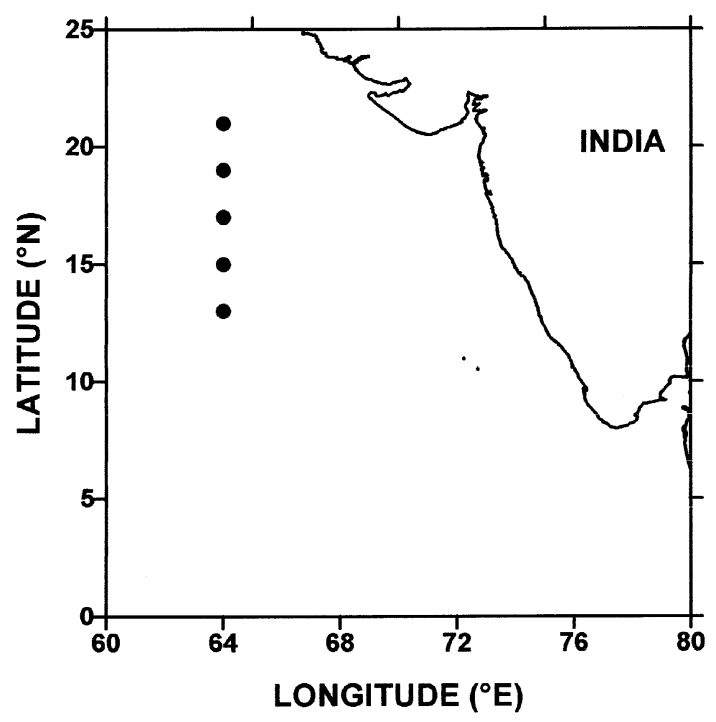

Figure 1. Sampling locations along $64^{\circ} \mathrm{E}$. field calculated and used for estimating total abundance by using the relationship given by Parsons et al (1984). These numbers were then used to calculate bacterial carbon biomass using the conversion of $20 \mathrm{fg}$ C cell ${ }^{-1}$ (Ducklow 1993).

Incorporation of tritiated $\left({ }^{3} \mathrm{H}\right)$ - methyl thymidine (specific activity $17000 \mathrm{mCi} / \mathrm{mmole}$, Bhabha Atomic Research Centre, Mumbai) by the water column bacteria was estimated following the method described in JGOFS Protocols (UNESCO 1994). Samples from surface to $150 \mathrm{~m}$ (usually from 1, 20, 40,60, 80, 100, 120 and $150 \mathrm{~m}$ ) were subjected for ${ }^{3} \mathrm{H}$ incorporation. An aliquot of $100 \mu \mathrm{l}$ working solution (59 nmole) was added to $20 \mathrm{ml}$ triplicate samples from each depth. These samples in $50 \mathrm{ml}$ polycarbonate centrifuge tubes (Tarsons, Calcutta) were incubated in the dark at $22-24^{\circ} \mathrm{C}$ (similar to the in situ temperatures in the mixed layer) for $60 \mathrm{~min}$. The uptake was terminated by adding $400 \mu \mathrm{l}$ formaldehyde. Samples were filtered through $0.22 \mu \mathrm{m}$ cellulose acetate filters (Millipore India Ltd, Bangalore) and the thymidine incorporated into macromolecular fractions was extracted/precipitated by three repeated, alternate rinses with cold trichloroacetic acid $(5 \mathrm{ml})$ and cold ethanol $(3 \mathrm{ml}$ for each rinse). The filters were stored in minivials, refrigerated and brought to the laboratory. After ensuring that they were moisture free, $4 \mathrm{ml}$ liquid scintillation fluid (cocktail-W, Spectrochem, Mumbai) was added and the samples were radio-assayed in a Packard TR 2500 liquid scintillation counter.

The ${ }^{3} \mathrm{H}$ thymidine incorporated (TTI) was calculated by the formula:

$$
\begin{aligned}
& T T \mathrm{I}\left(\mathrm{pMh}^{-1} \mathrm{l}^{-1}\right) \\
& =(\mathrm{DPM} s-\mathrm{DPM} b) / 2200 * V / 1000 * 60 / T * 1 / \mathrm{SA}
\end{aligned}
$$

where, DPM - disintegration per minute; $s$ - sample; $b$ - blank; $V$ - sample volume $(20 \mathrm{ml}) ; T$ - incubation time in minutes; SA - specific activity of added ${ }^{3} \mathrm{H}$ thymidine.

A conversion factor of $2.17 \times 10^{18}$ cells mole ${ }^{-1}$ thymidine incorporated was used to calculate bacterial production (Ducklow 1993). To estimate the bacterial carbon demand, we assumed a $33 \%$ efficiency of carbon assimilation by bacteria (i.e., one unit of bacterial carbon formed for every three units of organic carbon consumed).

Chemical quantification, microscopic counting and sizing of TEP were made from two sets of samples taken from 15 depths in the top $1000 \mathrm{~m}$. The first set of samples was transferred to clean glass bottles and used for chemical quantification within $30 \mathrm{~min}$ of collection. From the other set, $50 \mathrm{ml}$ samples were fixed by adding $1.0 \mathrm{ml} 37 \%$ formaldehyde and refrigerated until analyzed by microscopy.

Following the method of Passow and Alldredge (1995), the samples were filtered through $0.45 \mu \mathrm{m}$ polycarbonate or Durapore filters within a couple of hours of collection and stained with alcian blue $(0.1 \%$ 
wt/vol). The TEP were then dissolved in $80 \%$ sulphuric acid and the absorbance of the solution was read at 785 and/or $747 \mathrm{~nm}$ (see Kumar et al 1998). Concentrations of TEP were expressed as milligram equivalent of alginic acid (AA) $\mathrm{l}^{-1}$. Although for most samples, the TEP concentrations were calculated from single measurements, we did analyze a few samples from discrete depths in triplicates or quadruplicates and the mean coefficient of variation was within $11 \%$.

For microscopic counting and size measurements of TEP, aliquots of $10 \mathrm{ml}$ samples were filtered through $0.22 \mu \mathrm{m}$ (25 mm diameter) polycarbonate (Nuclepore, USA) or Durapore (Millipore India Ltd, Bangalore) filters. $100 \mu \mathrm{l}(0.1 \% \mathrm{wt} / \mathrm{vol})$ of alcian blue (8 GX Sigma, USA) and $20 \mu \mathrm{l}$ of $0.006 \%$ glacial acetic acid were added just before the last millilitre sample was vacuum drained. Filters were transferred to microscopic slides with immersion oil and readied for observation as per Parsons et al (1984). TEP were counted from at least 30 microscopic fields at a magnification of 200X. Some samples were observed under oil immersion at 1250X to note the association of bacterial cells and mineral particles with TEP. The average maximum length of TEP from each sample was calculated to understand the distribution of their sizes.

\section{Results}

During the summer monsoon of 1996, the mixed layer (ML) along $64^{\circ} \mathrm{E}$ was around $100-50 \mathrm{~m}$ with a shoaling towards the north. Nitrate concentrations were high $\left(\geq 1.0 \mu\right.$ mole $\left.^{-1}\right)$ in the ML Primary production in the upper $120 \mathrm{~m}$ column was in the range of 347$1782 \mathrm{mg} \mathrm{C} \mathrm{m}{ }^{-2} \mathrm{~d}^{-1}$. Phytoplankton cell numbers were invariably high in the range of $10^{4}-10^{5}$ cells $1^{-1}$. Bloom proportions of Phaeocystis were found in the north of $17^{\circ} \mathrm{N}$, (Madhupratap et al 2000).

Bacteria were abundant in the top $50 \mathrm{~m}$ ranging from 0.11 to $1.99 \times 10^{8} 1^{-1}$ (table 1 ). Their maximum

Table 1. Bacterial abundance and production in surface waters at various locations during the summer monsoon of 1996.

\begin{tabular}{|c|c|c|c|c|c|c|}
\hline Station & $\operatorname{Depth}(\mathrm{m})$ & $\mathrm{TDC} \times 10^{8} \mathrm{l}^{-1}$ & $\mathrm{BC} \mathrm{g} \mathrm{m}^{-3}$ & TTI $\mathrm{pMl}^{-1} \mathrm{~h}^{-1}$ & BCP $\mathrm{gm}^{-3} \mathrm{~d}^{-1}$ & BCD $g^{-3} d^{-1}$ \\
\hline \multirow[t]{6}{*}{$13^{\circ} \mathrm{N} 64^{\circ} \mathrm{E}$} & 0 & 1.453 & 0.029 & 0.491 & 0.0051 & 0.0168 \\
\hline & 20 & 1.371 & 0.027 & 0.992 & 0.0103 & 0.0339 \\
\hline & 40 & 1.996 & 0.039 & 1.850 & 0.0192 & 0.0633 \\
\hline & 60 & 0.249 & 0.0049 & 0.362 & 0.0037 & 0.0122 \\
\hline & 80 & 1.292 & 0.0258 & 0.880 & 0.0092 & 0.0303 \\
\hline & 100 & 0.411 & 0.0082 & 0.678 & 0.0070 & 0.0231 \\
\hline \multirow[t]{8}{*}{$15^{\circ} \mathrm{N} 64^{\circ} \mathrm{E}$} & 0 & 0.822 & 0.0164 & 1.182 & 0.0123 & 0.0406 \\
\hline & 20 & 1.174 & 0.0235 & 2.303 & 0.0239 & 0.0788 \\
\hline & 40 & 0.787 & 0.0157 & 1.477 & 0.0153 & 0.0505 \\
\hline & 60 & 0.811 & 0.0162 & 0.455 & 0.0047 & 0.0155 \\
\hline & 80 & 0.352 & 0.0070 & 1.281 & 0.0133 & 0.0439 \\
\hline & 90 & 0.423 & 0.0085 & 0.198 & 0.0020 & 0.0066 \\
\hline & 120 & 0.141 & 0.0028 & 0.642 & 0.0066 & 0.0218 \\
\hline & 150 & 0.106 & 0.0021 & NA & & \\
\hline \multirow[t]{8}{*}{$17^{\circ} \mathrm{N} 64^{\circ} \mathrm{E}$} & 0 & 0.235 & 0.0047 & 1.968 & 0.0204 & 0.0673 \\
\hline & 25 & 0.188 & 0.0037 & 1.352 & 0.0140 & 0.0462 \\
\hline & 40 & 0.305 & 0.0061 & 1.194 & 0.0124 & 0.0409 \\
\hline & 50 & 0.059 & 0.0012 & 0.679 & 0.0070 & 0.0231 \\
\hline & 75 & 0.411 & 0.0082 & 0.156 & 0.0016 & 0.0053 \\
\hline & 100 & 0.176 & 0.0035 & 0.229 & 0.0023 & 0.0076 \\
\hline & 120 & 0.296 & 0.0059 & 0.180 & 0.0018 & 0.0059 \\
\hline & 150 & 0.341 & 0.0068 & 0.460 & 0.0047 & 0.0155 \\
\hline \multirow[t]{8}{*}{$19^{\circ} \mathrm{N} 64^{\circ} \mathrm{E}$} & 0 & 0.904 & 0.0180 & 0.651 & 0.0068 & 0.0223 \\
\hline & 25 & 0.775 & 0.0155 & 0.428 & 0.0045 & 0.0146 \\
\hline & 40 & 1.197 & 0.0239 & 0.675 & 0.0071 & 0.0232 \\
\hline & 60 & 1.057 & 0.0211 & 0.349 & 0.0036 & 0.0119 \\
\hline & 75 & 0.951 & 0.0190 & 0.158 & 0.0017 & 0.0054 \\
\hline & 100 & 0.341 & 0.0068 & 0.021 & 0.0022 & 0.0072 \\
\hline & 120 & 0.294 & 0.0058 & 0.183 & 0.0019 & 0.0062 \\
\hline & 150 & 0.199 & 0.0039 & NA & & \\
\hline \multirow[t]{7}{*}{$21^{\circ} \mathrm{N} 64^{\circ} \mathrm{E}$} & 0 & 0.129 & 0.0025 & 0.705 & 0.0073 & 0.0242 \\
\hline & 25 & 0.106 & 0.0021 & 0.529 & 0.0055 & 0.0181 \\
\hline & 50 & 0.106 & 0.0021 & 0.127 & 0.0013 & 0.0043 \\
\hline & 75 & 1.291 & 0.0250 & 0.144 & 0.0015 & 0.0049 \\
\hline & 100 & 1.045 & 0.0209 & 0.112 & 0.0012 & 0.0038 \\
\hline & 120 & 1.221 & 0.0244 & 0.062 & 0.0007 & 0.0021 \\
\hline & 150 & 1.081 & 0.0216 & 0.223 & 0.0023 & 0.0765 \\
\hline
\end{tabular}

TDC: total direct (acridine orange) counts; BC: bacterial carbon biomass; TTI: thymidine incorporation rate; BCP: bacterial carbon production rate; BCD: bacterial carbon demand and, NA: no data. 


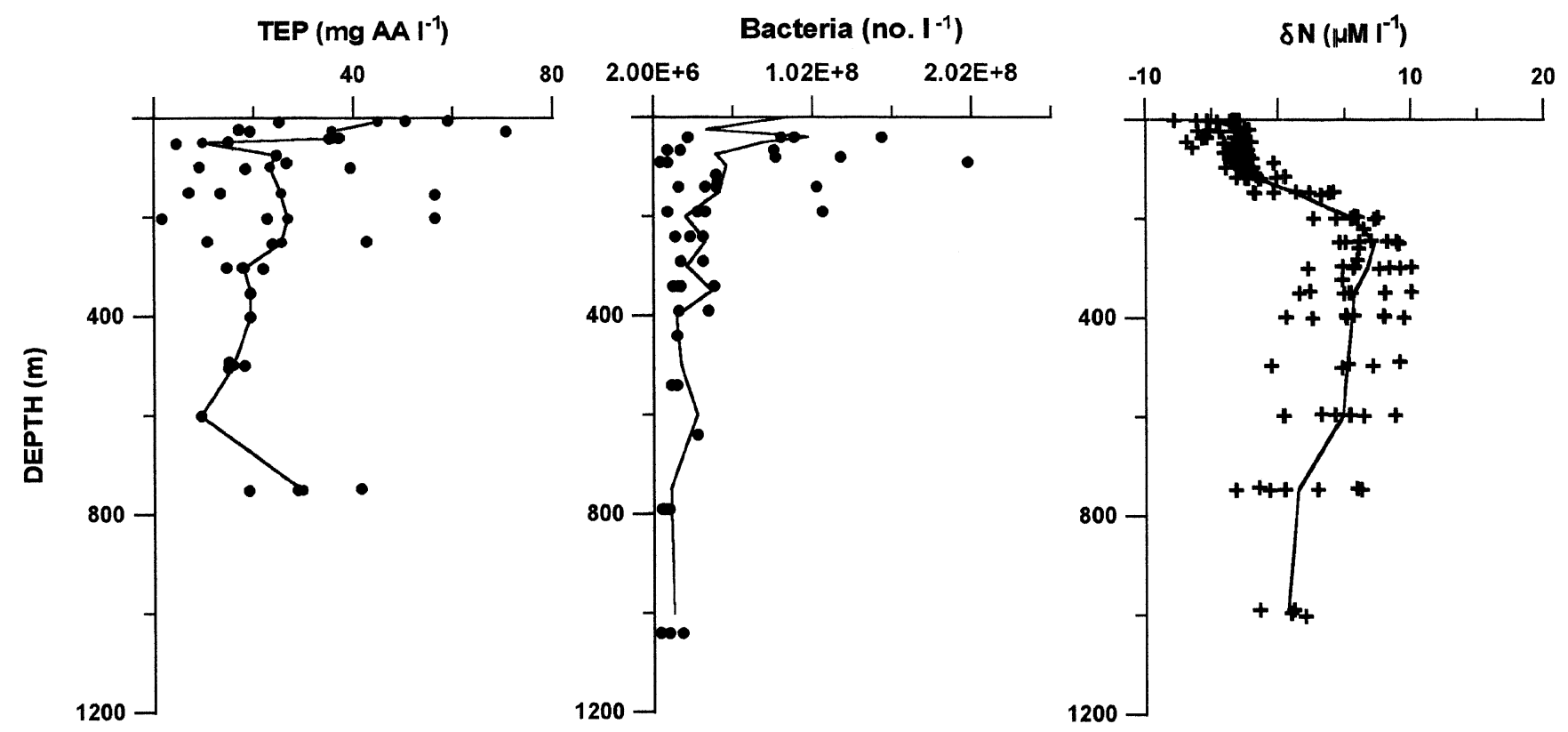

Figure 2. Vertical profiles of transparent exopolymer particles (TEP), bacterial counts and $\delta \mathrm{N}$ along $64^{\circ} \mathrm{E}$. Averages of each of these parameters are shown by solid lines.

concentration at the surface was $1.45 \times 10^{8}$ cells $\mathrm{l}^{-1}$ and, as can be discerned from figure 2 , decreased to ca. $2.0 \times 10^{7} \mathrm{l}^{-1}$ around $400 \mathrm{~m}$ and below. On an average, their numbers were $0.64 \times 10^{7} \mathrm{l}^{-1}$ in waters below the ML (150-500 m) that further decreased to $<0.11$ $\times 10^{7} \mathrm{l}^{-1}$ between 500 and $1000 \mathrm{~m}$. Their abundance was higher in the north of $17^{\circ} \mathrm{N}$. A secondary peak, with counts up to $0.91 \times 10^{7} \mathrm{l}^{-1}$, persisted ca. between 200 and $400 \mathrm{~m}$ at most sampling stations along $64^{\circ} \mathrm{E}$. Standing stocks of bacterial carbon (BC) ranged from 2.5 to $39 \mathrm{mg} \mathrm{m}^{-3}$ in the surface and from 0.4 to 0.82 $\mathrm{mg} \mathrm{m} \mathrm{m}^{-3}$ at $1000 \mathrm{~m}$. Bacterial carbon production (BCP), with thymidine incorporation rates ranging from 0.02 to $2.30 \mathrm{pM} \mathrm{l}^{-1} \mathrm{~h}^{-1}$ amounted to $2.2-23.98$ $\mathrm{mg} \mathrm{C} \mathrm{m} \mathrm{m}^{-1}$. Assuming a $33 \%$ efficiency of carbon assimilation by bacteria, the calculated BCD was in the range of 7.2 to $78.8 \mathrm{mg} \mathrm{C} \mathrm{m}^{-3} \mathrm{~d}^{-1}$ in the ML. As can be derived from the data in table 1, the 0-120 $\mathrm{m}$ column integrated values of $\mathrm{BC}, \mathrm{BCP}$ and $\mathrm{BCD}$ from different stations ranged respectively from 0.57 to $2.40 \mathrm{~g} \mathrm{~m}^{-2} ; 0.34$ to $1.35 \mathrm{~g} \mathrm{C} \mathrm{m}^{-2} \mathrm{~d}^{-1}$ and 1.02 to $4.04 \mathrm{~g}$ $\mathrm{C} \mathrm{m}^{-2} \mathrm{~d}^{-1}$.

Vertical profiles of TEP at different sampling locations are depicted in figure 2. TEP concentrations decreased with increasing depth from an average of about $60 \mathrm{mg} \mathrm{AA} \mathrm{eq} \mathrm{l}^{-1}$ in the surface to less than 10 $\mathrm{mg} \mathrm{AA} \mathrm{eq} \mathrm{l}^{-1}$ at $1000 \mathrm{~m}$. On the whole, TEP varied from $<5 \mathrm{mg}$ to as high as $102 \mathrm{mg} \mathrm{AA} \mathrm{eq} \mathrm{l}^{-1}$ in the water column (Kumar et al 1998). Additionally, their concentrations in surface waters $(1-50 \mathrm{~m})$ were more $\left(\geq 25 \mathrm{mg} \mathrm{AA} \mathrm{eq}{ }^{-1}\right.$ ) in the north, particularly, from 18 to $20^{\circ} \mathrm{N}$ and, very high concentrations were seen around $600 \mathrm{~m}$ at these stations. Vertical profiles of bacterial counts and nitrate deficit $(\delta \mathrm{N})$ - a measure of nitrate decrease due to its bacterial reduction to molecular nitrogen - are also included in figure 2 for comparison. It is seen that $\delta \mathrm{N}$ is around $0-7.5 \mu \mathrm{M}$ between 150 and $200 \mathrm{~m}$ where the bacterial numbers on an average were high, but the TEP were low.

Latitudinal distribution of mean lengths and counts of TEP along $64^{\circ} \mathrm{E}$ is shown in figures 3 and 4 respectively. Their sizes were bigger in the north of $17^{\circ} \mathrm{N}$. The numbers of discrete TEP were quite low with an overall range of 130 to $4650 \mathrm{ml}^{-1}$, owing generally to larger sizes (all samples mean length $47.33 \pm 28.19 \mu \mathrm{m}$, $n=38)$.

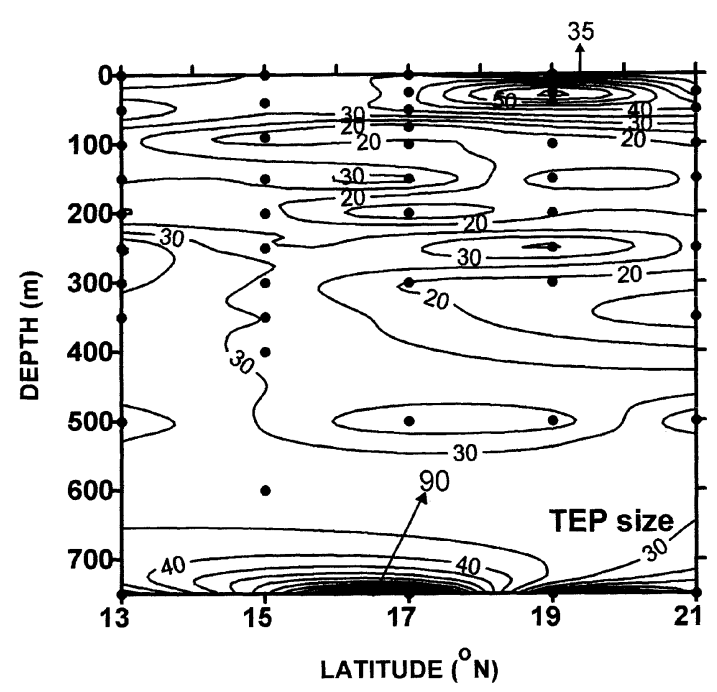

Figure 3. Distribution of TEP sizes $(\mu \mathrm{m})$ along $64^{\circ} \mathrm{E}$ during the 1996 summer monsoon. 


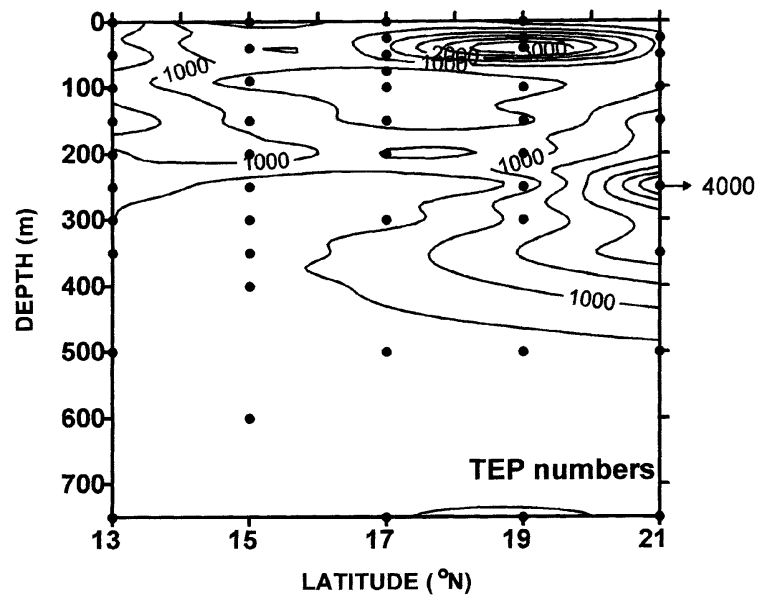

Figure 4. Distribution of TEP numbers $\left(\mathrm{ml}^{-1}\right)$ along $64^{\circ} \mathrm{E}$ during the 1996 summer monsoon.
Regression analyses of bacterial counts versus TEP concentration, size, counts and total organic carbon (figure 5) suggested that bacterial counts are more robustly correlated with TEP concentration $(r=0.6$; $n=57 ; P<0.01)$ than with TEP numbers $(r=0.50$; $n=60 ; P<0.01$ ), with TOC or TEP sizes. Positive linear relationship $(r=0.49 ; \quad n=22 ; \quad P<0.05)$ between TEP concentrations and bacterial production (figure 6) suggests that the TEP is in excess and bacterial production in upper $120 \mathrm{~m}$ is more or less uniform. Further, maximum rates of bacterial production appear to have been attained when TEP concentrations were equal to or even $10 \mathrm{mg} \mathrm{AA}$ eq $\mathrm{l}^{-1}$. This suggests that bacterial abundance and production are supported directly or indirectly by solubilization of TEP.
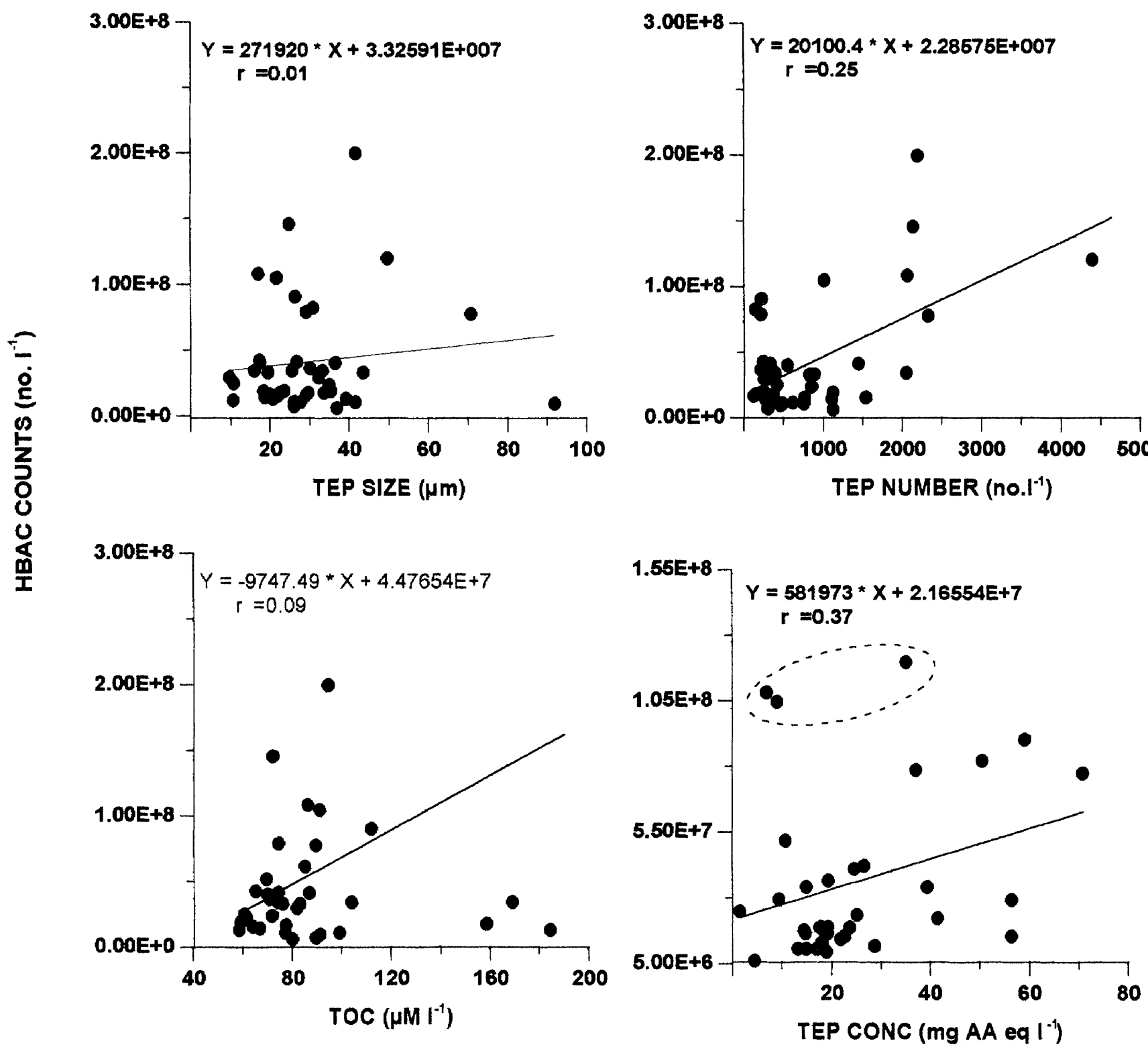

Figure 5. Scatter diagrams showing relationships of heterotrophic bacterial (H BAC) counts with: TEP size, TEP numbers, TEP concentrations and TOC during the 1996 summer monsoon. 


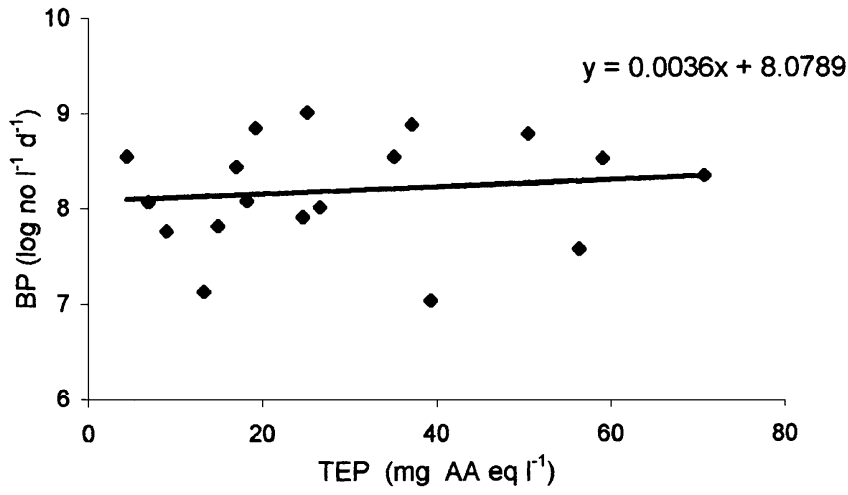

Figure 6. Regression relationship of bacterial production with TEP concentrations in the surface waters $(0-150 \mathrm{~m})$ along $64^{\circ} \mathrm{E}$ during the summer monsoon, 1996.
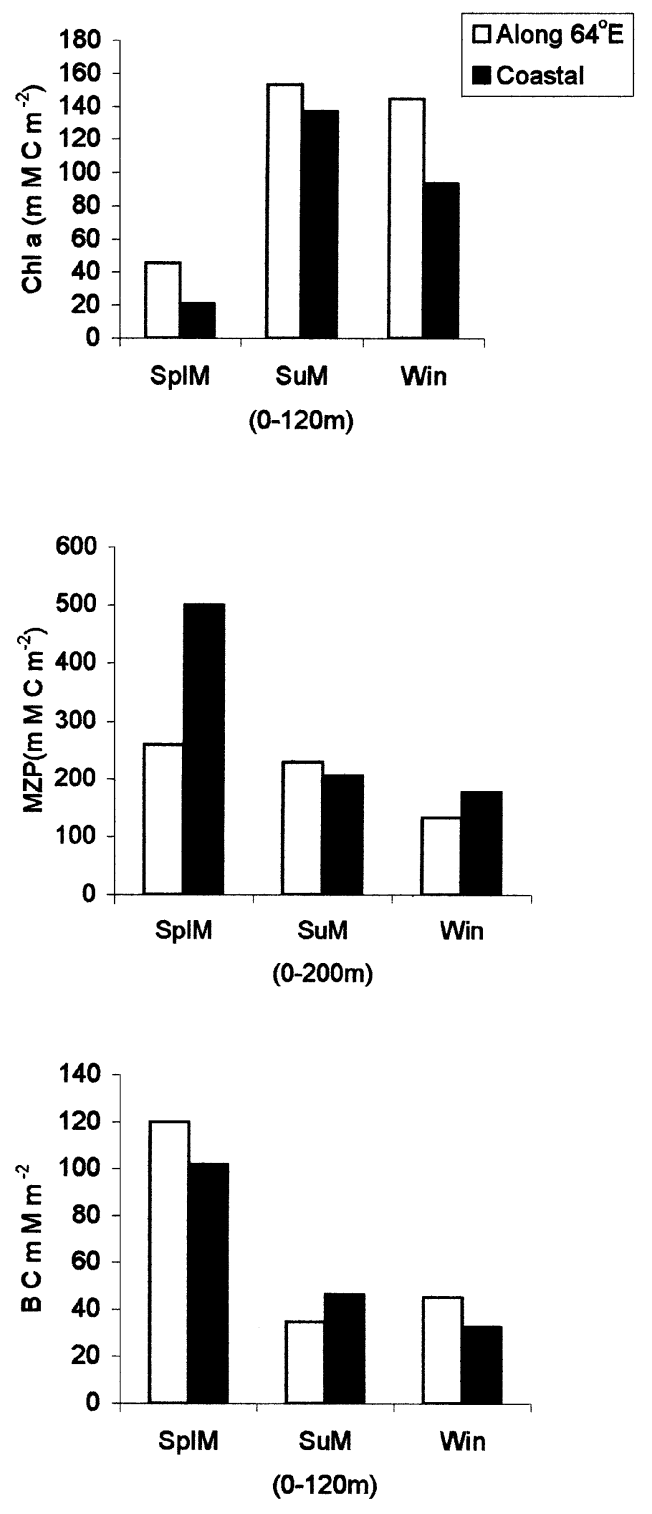

\section{Discussion}

The concentration of bacteria during summer monsoon was low compared to those in spring intermonsoon (April - May) period along $64^{\circ} \mathrm{E}$ (Ramaiah et al 1996). They are in the same range observed during the summer monsoon months (June - September) in other areas of open Arabian Sea (Goosen et al 1997, Wiebinga et al 1997). Bacterial production also agreed with ranges reported by Goosen et al (1997) and Wiebinga et al (1997) during southwest monsoon. This clearly suggests that a large area in the Arabian Sea experiences low abundance and production of bacteria during the summer monsoon. This fact is augmented by the occurrence of lower ratios of
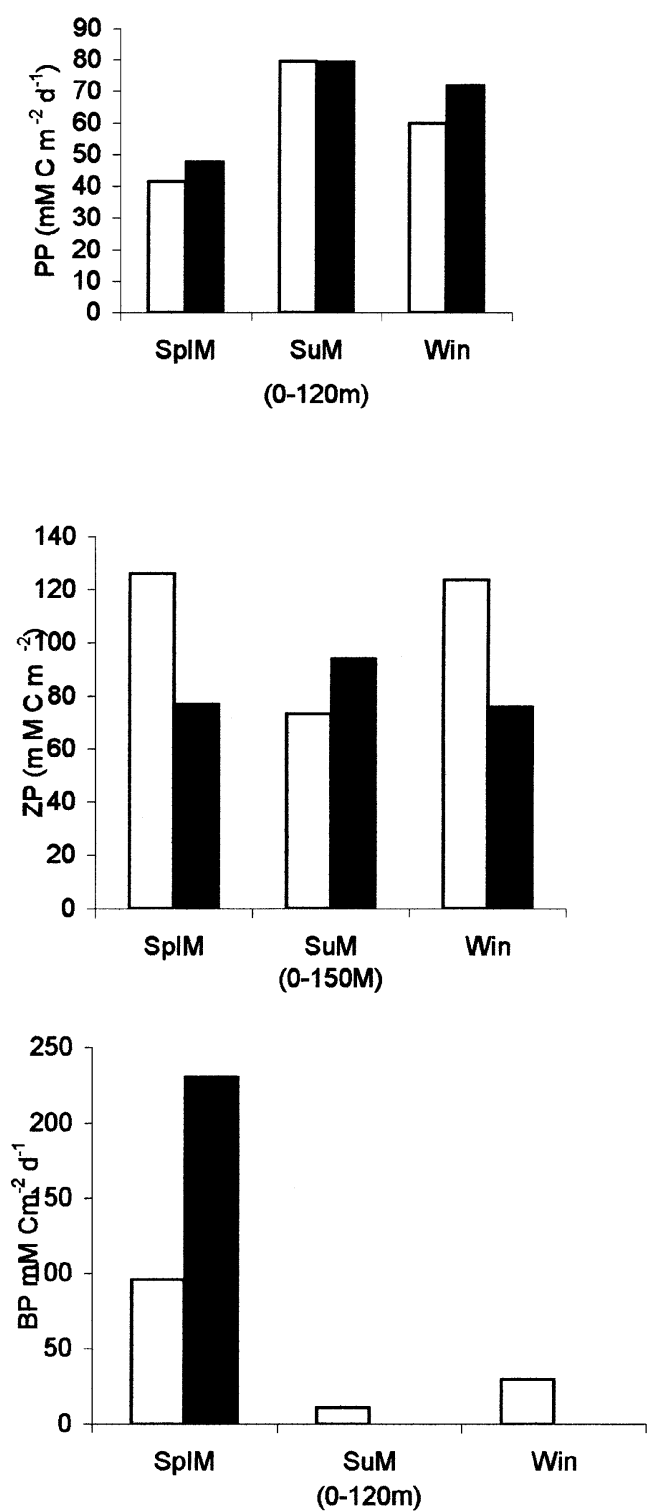

Figure 7. Living component carbon biomass in the sampling locations along $64^{\circ} \mathrm{E}$ and a transect along the west coast of India within $200 \mathrm{~m}$ depth contour. Carbon biomass is in $\mathrm{mM} \mathrm{C} \mathrm{m}{ }^{-2}$. PP denotes primary production; MZP, microzooplankton; ZP, mesozooplankton; BC, bacterial carbon standing stock; BP, bacterial production; SpIM, spring intermonsoon; SuM, summer monsoon and, Win denotes winter. 
bacterial/phytoplankton production (Wiebinga et al 1997; Prasanna Kumar et al 2000).

The sinking carbon flux from the surface is a result of either biologically mediated aggregation of photosynthetically formed organic matter or abiotically mediated coagulation of small, discrete particles into larger aggregates. The TEP are formed abiotically from dissolved extracellular polysaccharides (Passow et al 1994). Diatoms (Williams 1990) and some phytoplankton species (Lancelot and Methot 1985) produce TEP in abundance comparable to phytoplankton carbon (Passow et al 1994). For example, Phaeocystis spp are known to copiously exude over $50 \%$ of their photosynthate (Lancelot and Methot 1985) which might lead to formation of large concentrations of TEP. It is interesting to note that large sized particles (and concentrations) occurred around $600 \mathrm{~m}$ mostly to the north of $15^{\circ} \mathrm{N}$, in the Arabian Sea. This probably implies firstly, a rapid sinking of TEP immediately after formation from bloom proportions of Phaeocystis sp. The Phaeocystis bloom was in senescent stage (Madhupratap et al 2000). Secondly, it is possible that rapid sinking and lower temperatures (facilitating condensation of polysaccharides) below $400 \mathrm{~m}$ may have lead to their post-production aggregation leading to larger sized TEP. This is evident from their low numbers but larger sizes $(>50$ $\mu \mathrm{m})$ at $400-600 \mathrm{~m}$. Their smaller sizes $(20-30 \mu \mathrm{m})$ in the intermediate layers $(200-400 \mathrm{~m})$ may be suggestive of the microbial colonization and sheering by ectoenzyme hydrolysis as suggested by Martinez and Azam (1993). Despite a low level of statistical significance, the positive correlation $(r=0.136)$ between bacterial counts and TEP numbers observed during this study may be suggestive of the sheering of TEP in this depth zone in particular. Heterotrophic bacteria are efficient in direct uptake of low-molecular weight dissolved organic matter. Upon attaching, adsorbing or 'packaging' to TEP, bacteria elaborate ectoenzymes, dissolve the easily assimilable TEP and incorporate this into their cells. Recent studies suggest such a role for water column bacteria (Chrost 1990; Azam et al 1993; Smith et al 1995). The stronger relationship between the water column bacterial abundance (as also their production) and TEP concentrations in the Arabian Sea corroborates with the earlier suggestions.

Microbial denitrification is a biochemically complex, high energy requiring process (Brock et al 1991). Ducklow (1993) and Naqvi and Shailaja (1993) found that bacterial carbon demand in the denitrification zone is greater than the sinking carbon flux and suggested a large scale, lateral import of organic matter into mesopelagic zone. The estimated carbon demands for the Arabian Sea intermediate water denitrification range from ca. $155 \mathrm{mg} \mathrm{C} \mathrm{m}^{-2} \mathrm{~d}^{-1}$ (Naqvi et al 1996) to 346-518 mg C m${ }^{-2} \mathrm{~d}^{-1}$ (derived from Banse 1994) to 519-2274 mg C m${ }^{-2} \mathrm{~d}^{-1}$ (calculated from Ducklow
1993). During summer monsoon, bacterial production in $0-300 \mathrm{~m}$ column is reported to range from 148 to $223 \mathrm{mg} \mathrm{C} \mathrm{m}^{-2} \mathrm{~d}^{-1}$ in the Somali Basin (Wiebinga et al 1997). Extrapolating our assumption of $33 \%$ efficiency of carbon assimilation for such production rates, the BCD amounts to $444-669 \mathrm{mg} \mathrm{C} \mathrm{m}^{-2} \mathrm{~d}^{-1}$ in the 0-300 m column. Despite seasonal differences (lower during intermonsoon: $322-404 \mathrm{mg} \mathrm{C} \mathrm{m} \mathrm{C}^{-1}$ and higher during winter: 662-1150 $\mathrm{mg} \mathrm{C} \mathrm{m}^{-2} \mathrm{~d}^{-1}$ (data from Sarin et al. 1996)), sediment trap and ${ }^{234} \mathrm{Th}$ export fluxes do suggest a noticeable carbon export at $100 \mathrm{~m}$. In addition, the total organic carbon (TOC) concentrations in the region are high varying from 960 to $1440 \mathrm{mg} \mathrm{m}^{-3}$ (Menzel 1964); $1600 \mathrm{mg} \mathrm{m}^{-3}$ in the surface layers to $>3600 \mathrm{mg} \mathrm{m}^{-3}$ (Kumar et al 1990) and from 580 to $>960 \mathrm{mg} \mathrm{m}^{-3}$ (Hansell and Peltzer 1998). It may be added here that although the labile proportions of this TOC are not known, it is speculated variously that only less than $10 \%$ of the TOC may ultimately be refractory (Azam et al 1994). From these trends in TOC, particle fluxes, from our TEP data and from the significant relationship between TEP and BP in the Arabian Sea, we infer that a greater portion of BCD is met from the TEP. Thus, TEP are important in fuelling the Arabian Sea suboxic, subsurface denitrification process. Further, from the measurements of Ducklow (1993) and Wiebinga et al (1997), it is evident that the bacterial production rates are lower in the deeper layers. This is also clear from the substantially decreasing bacterial counts observed during this study. Hence, the BCD would be lower in the deeper layers. The cumulative fractions of TEP and slow-to-degrade dissolved organic carbon in the sinking flux must be sufficient for metabolism of bacterial communities.

Azam et al (1994) suggest that bacteria utilize DOC with highly variable carbon assimilation efficiency of $10-70 \%$ and their communities in the denitrification zone may differ in metabolic capacities than those from the surface. Our assumption of $33 \%$ efficiency for bacterial carbon formation is similar to those given by Smith et al (1995) but quite low when compared with those assuming 50\% efficiency (Ducklow 1993). Even at this 'moderately low' efficiency it appears that there is enough TEP to fuel bacterial metabolism during denitrification. Further, the generation times of bacteria in the surface $(0-120 \mathrm{~m})$ waters along $64^{\circ} \mathrm{E}$ range from 5.5 to 19 days during different seasons (Ramaiah, unpublished) suggesting faster carbon turnover than those estimated by Wiebinga et al (1997) for the northwestern Arabian Sea bacteria.

Results of biological studies during the 1996 southwest monsoon together with those in other seasons under the Arabian Sea JGOFS (India) Programme are summarized in figure 7 . An overview of the living component of carbon biomass and its seasonal variations along $64^{\circ} \mathrm{E}$ and coastal stations (occupied 
by JGOFS India Programme) is also summarized in this figure. It is evident that the bacterial community is dominant during spring intermonsoon (see also Ramaiah et al 1996; Campbell et al 1998). During April - May, when chlorophyll concentrations and primary production are low (Bhattathiri et al 1996), bacteria appear to be very important in sustaining a greater abundance of microzooplankton (Gauns et al 1996) as well as of mesozooplankton through the microbial loop (Madhupratap et al 1996a). The latter's biomass in the mixed layer is considered to be invariant (Madhupratap et al 1996b). Bacterial production through organic carbon assimilation appears to be of greater significance for microzooplankton both during summer monsoon and spring intermonsoon (Gauns et al 1996). Feeding on bacteria which are nutritionally 'more complete', would be a more efficient means of "better nutrition" for microzooplankton. In addition, the heterotrophic bacterial community is the key component breaking down organic substances and making available most inorganic nutrients essential for autotrophic production in euphotic zone. The strong relationship between bacterial abundance and concentrations of TEP indicate that TEP in the Arabian Sea play an important role in sustaining these heterotrophic communities which appear to be of greater significance during spring intermonsoon.

In conclusion, TEP concentrations measured during the summer monsoon appear to be sufficient for fuelling bacterial metabolism in the suboxic denitrification layers of the Arabian Sea. However, we do not yet know the actual carbon content of TEP. Recently, Alldredge (1998) hypothesized that up to $14-37 \%$ of the "miscellaneous aggregates" (we presume that TEP are a major fraction of this class) is carbon. Assuming that $100 \mathrm{mg}$ alginic acid equivalent of TEP will at least have $20 \mathrm{mg}$ carbon, their carbon equivalent between 200 and $1000 \mathrm{~m}$ is about $300 \mathrm{mg}$ $\mathrm{m}^{-3}$. Thus, results from this study strongly suggest that TEP concentrations may meet bacterial carbon demand for denitrification in the Arabian Sea. Our measurements on TEP are the first ones from the Arabian Sea and future studies would prove helpful in understanding the annual cycles of their concentrations and sizes, as well as their role in carbon cycling in the Arabian Sea.

\section{Acknowledgements}

We thank Dr. E Desa, Director NIO for facilities and encouragement. We also thank Drs. S Raghukumar and N B Bhosle at the NIO for helpful suggestions. Financial support by the Department of Ocean Development, New Delhi for JGOFS (India) Programme under which this study was carried out is gratefully acknowledged. This is NIO contribution no. 3584 .

\section{References}

Alldredge A L, Passow U and Logan B E 1993 The abundance and significance of a class of large, transparent organic particles in the ocean; Deep-Sea Res. 40 1131-1140

Alldredge A L 1998 The carbon, nitrogen and mass content of marine snow as a function of aggregate size; Deep-Sea Res. 45 529-541

Azam F, Martinez J and Smith D C 1993 Bacteria-organic matter coupling on marine aggregates; In: Trends in microbial ecology (ed) R Guerrero and C Pedros-Alio (Barcelona: Spanish Society for Microbiology) pp 410-414

Azam F, Steward G F, Smith D C and Ducklow H W 1994 Significance of bacterial in carbon fluxes in the Arabian Sea; Proc. Indian Acad. Sci., (Earth Planet Sci.) 103 341-351

Banse K 1994 On the coupling of hydrography, phytoplankton, zooplankton offshore in the Arabian Sea and organic particles settling to depth. In: Biogeochemistry of the Arabian Sea; Lal D (ed), (Bangalore: Indian Academy of Sciences) pp 125-161

Bhattathiri P.M.A, Aditi Pant, Sawant S, Gauns M Matonkar S G P and Mohanraju R 1996 Phytoplankton production and chlorophyll distribution in the eastern and central Arabian Sea in 1994-95; Curr. Sci. 71 857-862

Biddanda B and Benner R 1997 Major contribution from mesopelagic plankton to heterotrophic metabolism in the upper ocean; Deep-Sea Res. 14 2069-2085

Bodungen B van, Smetacek V, Tilzer MM and Zeitzschel B 1986. Primary production and sedimentation during spring in the Antarctic Peninsula region; Deep-Sea Res. 33 177-194

Brock J C, McClain M C, Luther M E and Hay W W 1991 The phytoplankton bloom in the northwestern Arabian Sea during the southwest monsoon of 1979; J. Geophys. Res. 96 20623-20642

Burkill P H, Mantoura R F C and Owens N J P 1993 Biogeochemical cycling in the northwestern Indian Ocean: A brief overview. Deep-Sea Res., special issue on Biogeochemical cycling in the northwestern Indian Ocean (ed) $\mathrm{P} \mathrm{H}$ Burkill, R F C Mantoura, N J P Owens, 40 643-649

Campbell L, Landry M R, Constantinour J, Nolla, H A, Liu H, Brozn S L, Caron D A 1998 Response of microbial community structure to environmental forcing in the Arabian Sea; Deep-Sea Res. 45 2301-2325

Chrost R J 1990 Microbial ectoenzymes in aquatic environments; In: Aquatic microbial ecology: Biochemical and molecular approaches (ed) J Overbeck and R J Chrost (New York: Brock/Springer) pp. 47-78

Ducklow H W 1993. Bacterioplankton distributions and production in the northwestern Indian Ocean and Gulf of Oman, September 1986; Deep-Sea Res. 40 753-771

Gauns M, Mohanraju R and Madhupratap M 1996 Studies on the microzooplankton from the central and eastern Arabian Sea; Curr. Sci. 71 874-877

Goosen N K, Van-Rijswijk P, Kromkamp J, Peena J 1997 Regulation of annual variation in heterotrophic bacterial production in the Schelde Estuary (SW Netherlands); Aquat. Micro. Ecol. 12 223-232

Haake B, Ittekkot V, Rixen T, Ramaswamy V, Nair R R, Curry W B 1993 Seasonality and interannual variability of particle fluxes to the deep of the Arabian Sea; Deep-Sea Res. 40 1323-1344

Hansell D A and Peltzer E T 1998 Spatial and temporal variations of total organic carbon in the Arabian Sea; DeepSea Res. 45 2171-2194

Kumar M D, Rajendran A, Somasundar K, Haake B, Jenisch A, Shuo Z, Ittekkot V and Desai B N 1990 Dynamics of dissolved organic carbon in the northwestern Indian Ocean; Mar. Chem. 30 299-316 
Kumar M D, Sarma V V S S, Ramaiah N and Gauns M 1998 Biogeochemical significance of transparent exopolymer particles in the Indian Ocean; Geophys. Res. Lett. 25 81-84

Lancelot C and Methot S 1985 Biochemical fractionation of primary production by phytoplankton in Belgian coastal waters during short and longterm incubations with ${ }^{14} \mathrm{C}$ bicarbonate II. Phaeocystis pouchetti colonial population; Mar. Biol. 86 227-232

Madhupratap M, Prasanna Kumar S, Bhattathiri P M A, Kumar M D, Raghukumar S, Nair K K C, Ramaiah N 1996a Mechanism of the biological response to winter cooling in the northeastern Arabian Sea; Nature 384 452-549

Madhupratap M, Gopalakrishnan T C, Haridas P, Nair K K C, Aravindakshan P N, Padmavati G and Shinney Paul 1996b Lack of seasonal and geographic variation in mesozooplankton biomass in the Arabian Sea and its structure in the mixed layer; Curr Sci. 71 863-868

Madhupratap M, Sawant S and Gauns M 2000 A first report on a bloom of the marine prymnesiophycaen Phaeocystis globosa from the Arabian Sea; Oceanologica Acta 2383-2390

Martinez J and Azam F 1993 Periplasmic aminopeptidase and alkaline phosphatase activities in a marine bacterium: Implications for substrate processing in the sea; Mar. Ecol. Prog. Ser. 92 89-97

Menzel D W 1964 The distribution of dissolved organic carbon in the western Indian Ocean; Deep-Sea Res. 11 757-766

Nair R R, Ittekkot V, Managanin S J, Ramaswamy V, Haake B, Degens E T, Desai B N and Honjo S 1989 Increased particle flux to the deep ocean related to monsoons; Nature 338 749-751

Naqvi S W A 1994 Denitrification processes in the Arabian Sea; Proc. Indian Acad. Sci. (Earth Planet. Sci.) 103 279-300

Naqvi S W A and Shailaja M S 1993 Activity of the respiratory electron transport system and respiration rates within the oxygen minimum layer of the Arabian Sea; Deep-Sea Res. 40 687-695

Naqvi S W A, Shailaja M S, Kumar M D and Gupta R S 1996 Respiration rates in subsurface waters of the northern Indian Ocean: Evidence for low decomposition rates of organic matter within the water column in the Bay of Bengal; DeepSea Res. 43 73-81

Naqvi S W A, Yoshinari T, Jayakumar D A, Altabet M A, Narvekar P V, Devol A H, Brandes J A, Codispoti L A 1998 Budgetary and biogeochemical implication of $\mathrm{N}_{2} \mathrm{O}$ isotope signatures in the Arabian Sea; Nature 394 462-464

Parsons T R, Maita Y, Lalli C M 1984 A manual of chemical and biological methods for sea water analysis, (Oxford: Pergamon Press)
Passow U and Alldredge A L 1994 Distribution, size and bacterial colonization of Transparent Exopolymer Particles (TEP) in the ocean; Mar. Ecol. Prog. Ser. 113, 185-198

Passow U and Alldredge A L 1995 A dye-binding assay for the spectrophotometric measurement of Transparent Exopolymer Particles (TEP); Limnol. Oceanogr. 40 1326-1335

Pomroy A J and Joint I R 1999 Bacterioplankton activity in the surface waters of the Arabian Sea during and after the 1994 SW monsoon; Deep-Sea Res. 46 767-794

Prasanna Kumar S, Ramaiah N, Mangesh Gauns, Sarma V V S S, Muraleedharan P M, Raghukumar S., Dileep Kumar M and Madhupratap M Time-Series analyses of the physical, chemical and biological characteristics of the northeastern Arabian Sea during winter; Deep-Sea Res. (in press)

Qasim S Z 1982 Oceanography of the Northern Arabian Sea; Deep-Sea Res. 29 1041-1068

Ramaiah N, Raghukumar S and Gauns M 1996 Bacterial abundance and production in the central and eastern Arabian Sea; Curr. Sci. $\mathbf{7 1} 878-882$

Sarin M M, Rengarajan R and Ramaswamy V $1996{ }^{234} \mathrm{Th}$ scavenging and particle export fluxes from the upper $100 \mathrm{~m}$ of the Arabian Sea; Curr. Sci. 71 888-893

Smith D C, Steward G F, Long R A and Azam F 1995 Bacterial mediation of carbon fluxes during a diatom bloom in a mesocosm; Deep-Sea Res. 42 75-98

Smith S L, Codispoti L A, Morrison J M and Barber R T 1998 The 1994-1996 Arabian Sea Expedition: an integrated, inter disciplinary investigation of the northeastern Indian Ocean to monsoonal forcing; Deep-Sea Res. 45 1905-1915

Takahashi K 1986 Seasonal fluxes of pelagic diatoms in the subarctic Pacific, 1982-1983; Deep-Sea Res. 33 1225-1251

UNESCO 1994 Protocols for the Joint Global Ocean Flux Study (JGOFS) Core Measurements, IOC Manuals and Guides 29, UNESCO, Paris, 170 pp

Veldhuis M J W, Kraay G W, van Bleijswijk J D L and Baars M A 1997 Abundance of bacterioplankton in relation to seasonal upwelling in the northwest Indian Ocean; Deep-Sea Res. 44 451-476

Wiebinga C J 1994 Bacterioplankton; In: Monsoons and Pelagic Systems. Netherlands Indian Ocean Programme Cruise Reports. Volume 1 (ed) M A Baars (Leiden: National Museum of Natural History) pp. 55-58.

Wiebinga C J, Veldhuis M J W and De-Baar H J W 1997 Abundance and productivity of bacterioplankton in relation to seasonal upwelling in the northwest Indian Ocean; DeepSea Res. 14 451-476

Williams P M 1990 Studies of the physical and chemical stability of natural sea surface films; Technical Report, Scripps Institute of Oceanography, La Jolla, CA (USA) $3 \mathrm{pp}$ 